\title{
PAGYVENUSIO AMŽIAUS MOTERŲ SAVIJAUTAI ITAKOS TURINTYS VEIKSNIAI
}

\author{
Nijolė Šostakienė, Ingrida Baranauskienė \\ Klaipedos universitetas
}

\begin{abstract}
Anotacija
Besikeičianti socioekonominė situacija, nuolatinis stresas darbe ir asmeniniame gyvenime, ilgejjantis pensinis amžius, didejjanti įtampa pasaulyje veikia žmonių savijautą. Antrinẻ literatūros šaltinių analizė atskleidè, kad pagyvenusio amžiaus moterų savijautai ir sveikatai įtakos turi šie veiksniai: žemas socialinis ir ekonominis statusas, fizinio ar psichologinio krūvio darbe sukeliamas stresas, nepalanki darbo ir šeimos sąveika, genetiniai ir biologiniai veiksniai, moterų dalyvavimas sveikatos priežiūros sistemoje, šeimyninės aplinkybės, gyvenimo būdas ir asmens saviraiška. Naratyvinis tyrimas (penkių moterų istorijų pagrindu sukurtas pasakojimas) neprieštarauja mokslo studijoje aprašytiems veiksniams, juos papildo, atsiskleidžia naujais aspektais, kitu turiniu. Išryškejjo veiksnių tarpusavio sąveika.
\end{abstract}

PAGRINDINIAI ŽODŽIAI: pagyvenusio amžiaus moterys, savijauta, įtakos turintys veiksniai.

\begin{abstract}
A changing socio-economic situation, constant stress at work and in personal life, receding retirement age and increasing tension in the world in general highly influence well-being of people. Secondary analysis of literary sources revealed that well-being of elderly women was impacted by the following factors: low social and economic status; stress caused by physical or psychological load at work, unfavourable interaction between work and family, genetic and biological factors, women's participation in the system of health care, influence of family circumstances, lifestyle and personal self-expression. The narrative research (a narration created on the ground of the life stories of five women) does not contradict the factors found in the scientific study, but rather complements them, it is revealed in new aspects, with a different content. The interaction of the factors is emphasised.

KEY WORDS: elderly women, well-being, determining factors.
\end{abstract}

DOI: http://dx.doi.org/10.15181/tbb.v76i1.1516

\section{Ivadas}

Besikeičianti socioekonominė situacija, nuolatinis stresas darbe ir asmeniniame gyvenime, ilgèjantis pensinis amžius, didèjanti įtampa pasaulyje labai veikia žmonių savijautą. Dar praejusiame šimtmetyje aktyviai diskutuota, kas lemia vyrų ir moterų sveikatą - biologiniai ar socialiniai veiksniai (Bird, Rieker, 1999). Nors „,biologiniai veiksniai, tokie kaip genetika, (...) hormonų poveikis, yra labai svarbūs, ne mažiau moterų ir vyrų sveikatą veikia ir socialiniai procesai" (Bird, Rieker, 1999, p. 745). Jie gali „nulemti, pagerinti ar pabloginti biologinę sveikata““ (Ten pat). Autorių nuomone, tai turi suprasti ir su tuo susijusius iššūkius spręsti mokslininkai, gydytojai, politikai, patys žmonės (Ten pat). Lietuvių mokslininkai V. Leonavičius, G. Baltrušaitytė, G. Raila, I. Naujokaitė (2013) atkreipia dèmesi i me- 
diciniškai nepaaiškinamų negalavimų paplitimą. Svarstydami, kaip medikai galètų valdyti ṣ̨̌ reiškinį, teigia, kad „dideja tiesioginis socialinių sąlygų poveikis asmens subjektyviai savijautai, nesukeliantis biofiziologinių kūno pokyčių“(Leonavičius, Baltrušaitytė, Raila, Naujokaitè, 2013, p. 32). R. Kuodytė-Kazilienè, R. Užaitė, R. Palinauskienė, A. Kuzinkovas, L. Šerytė, R. Ulianskienė (2007) analizavo streso, depresiškumo, nerimo paplitimą tarp sveikatos priežiūros ir švietimo darbuotojų. Jų teigimu, šis reiškinys yra labai paplitęs. Kiti autoriai, pvz., R. Ustinavičiené, V. Obelenis, D. Ereminas (2004) atkreipè dėmesị, kad „besikeičiantis darbo pobūdis sumažino ,tradicinių“ profesinių ligų skaičių, bet atsirado nauja problema - su darbu susijusių patologijų paplitimas - tai kaulų ir raumenų sistemos pažeidimai, streso sukeltos ligos, profesinès onkologinès ligos" (Ustinavičienè, Obelenis, Ereminas, 2004, p. 897). Mūsų tyrimo kontekste ypač svarbūs G. Rapolienès tyrimo rezultatai, atskleidžiantys, kad „Lietuvos pagyvenusių žmonių socialinis identitetas artimesnis <...> skurstančiųjų identitetui“ (Rapolienė, 2007, p. 109).

Kaip vieną iš savijautą lemiančių veiksnių V. Gudžinskienė, J. Amonienė, A. Pocevičius (2012) ịvardija fizinị aktyvumą. Kiti autoriai pabrèžia kūno kultūros ir sporto svarbą apskritai žmogaus gyvenime (Dadelo, 2013). Z. Javtokas (2009) akcentuoja visapusiškos fizinès, dvasinès ir socialinès gerovès įtaką žmogaus sveikatai.

Didelis dėmesys mokslinèse diskusijose skiriamas moters sveikatai. Moters sveikata nagrinejjama įvairiais aspektais: skurdas ir psichinè sveikata (Belle, 1990); stresas darbe ir moters sveikata (Burke, 2002; Repetti, Matthews, Waldron, 1989); chroniško streso ir nuolatinès socialinès įtampos įtaka moterų sveikatai (McDonough, Walters, Strohschein, 2002; Matthews, Shumaker, Langer, Hunt, Kaplan, Klesges, Ritenbaugh, 1997); pagyvenusių moterų sveikata rasiniu aspektu (Joyce, Bromberger, Harlow, Avis, Kravitz, Cordal, 2004); streso ịtaka krūties vėžiui (Dooley, Slavich, Moreno, Bower, 2017); gyvenimo kokybės ir socialinių veiksnių tarpusavio ryšys (Juozulynas, Jurgelènas, Prapiestis, Butikis, 2010); fizinio aktyvumo poveikis vyresnio amžiaus moteru psichofizinei sveikatai (Klizas, Sipavičienè, Klizienè, Pliauga, 2012); menopauzès ir socialinių veiksnių sąveika (Kuh, Wadsworth, Hardy, 1997); smurto sukelto streso įtaka moters sveikatai (Sutherland, Bybee, Sullivan, 2002); interneto svarba formuojant moterų požiūrị i sveikatą (Sanjay, John, Tiwary (2003). Lietuvos mokslininkai G. Šurkienè ir kt. nustatė, kad „moterys savo sveikatą vertina blogiau negu vyrai“ (Šurkienė, Stukas, Kučingis, Strujeva, 2004, p. 9).

Antrinè literatūros šaltinių analizė leido išskirti šiuos pagyvenusio amžiaus moterų savijautai ir sveikatai ịtakos turinčius socialinius veiksnius, kuriuos santykinai ịvardijome kaip neigiamus, neutralius ir teigiamus. Prie neigiamų veiksnių priskirtume: žemą socialinị ir ekonominị statusą, pvz., „,skurdas yra sudètingas reiškinys, 
lemiantis plataus masto pasekmes“ (Belle, 1990, p. 388); „moterys, užimančios žemesnį profesinį statusą, nurodè, kad yra mažiau patenkintos darbu (...) ir turi daugiau fizinès sveikatos problemų“ (Burke, 2002, p. 99).

Neigiamus su darbu susijusius veiksnius galima skirstyti ị kelias grupes: fizinio krūvio sukeliamas stresas, pvz., „tie patys fiziniai judesiai, ribotos judejjimo galimybės“ (Burke, 2002, p. 95); psichologinis ir fizinis smurtas darbe, pvz., ,anekdotai ar garsiai pasakytos pastabos, fizinė prievarta, stumdymas, spjaudymas ir pan." (Burke, 2002, p. 95); darbo ir veiklos šeimoje konfliktas, pvz., „moterys, dirbančios daugiau valandų, pasižymi labiau išreikštais psichosomatiniais simptomais“ (Burke, 2002, p. 96).

Prie neutralių veiksnių priskirtume: genetinius ir biologinius (juos priimame kaip duotybę); sveikatos priežiūros (pvz., ,pacientas ima domètis gydymo procesu“ [Leonavičius ir kt., 2013, p. 11-35]); aplinkos (pvz., ,asmuo turi aktyviai ieškoti optimalaus santykio su aplinka“ [Leonavičius ir kt., 2013, p. 11-35]); šeimyninès padèties (pvz., „moterų, gyvenančių šeimoje, kurioje dirba abu tèvai, bei turinčių vaikų, sveikata yra geresnè, nepaisant dažniau patiriamo streso“ [McDonough ir kt., 2002, p. 767-782]).

Kaip teigiamus veiksnius ịvardytume: sveiką gyvenseną (pvz., „fiziškai aktyvios moterys labiau rūpinasi savo išvaizda ir sveikata" [Klizas ir kt., 2012, p. 267-272]); asmens saviraišką (pvz., „kūno kultūros ir sporto mokslas turètų padèti spręsti uždavinius, susijusius su asmenybès, kaip socialinès-biologinès savireguliacinès sistemos, funkcionavimu“ [Dadelo, 2013, p. 55]).

\section{Metodologija}

Darbinè koncepcija. Pasirinkdamos kokybinę tyrimo prieigą - naratyvą straipsnio autorès daugiausia rèmési A. De Fina, A. Georgakopoulou (2015), J. Creswell (2003), A. Georgakopoulou (2014), B. Bitino, L. Rupšienès, V. Žydžiūnaitès (2008) darbais, kurie padèjo susiformuoti naratyvo, kaip tyrimo koncepcijos, suvokimą.

Mūsų atveju naratyvas - tai ị diktofoną įrašyti, vèliau užrašyti ir iššifruoti pasakojimai, kuriuose penkios pagyvenusios moterys nuo 56 iki 60 metų pasakoja apie savo savijautą per pastaruosius trejus metus. Visų penkių moterų prašyta apibūdinti savo savijautą, pasakojimą skatinant panašiais klausimais: kaip jūs šiandien jaučiatės; ar jūs patenkinta savo savijauta; kaip manote, kas labiausiai veikia jūsų sveikatą; kokiomis aplinkybėmis jūs jaučiatès gerai; kas nulemia jūsų prastą savijautą; ką darote, kad jaustumètės geriau; kaip jūs norètumète jaustis ir pan. Siekta, kad moterys pačios ,vadovautu““ pokalbiui, pačios išsakytu tai, kas joms svarbu. Jos nepertraukinètos, kartais prašyta patikslinti vieną ar kitą detalę. Perfrazuojant 
A. Georgakopoulou, galima teigti, kad mūsų naratyvas - penkios trumpos istorijos, susietos ị vieną pasakojimą (plg. Georgakopoulou, 2014), kuriuo siekiama suvokti pagyvenusių moterų sveikatai įtakos turinčius veiksnius respondenčių požiūriu.

Pristatant tyrimų rezultatus taikytas Jean-Lous Le Moigne sukonstruotas sisteminès analizės modelis, kuri analizavo J. Ruškus (1998-1999). Jean-Lous Le Moigne teigimu, aprašant bet kurị socialinį reiškinį visada vertinga pažvelgti i ji iš raidos, aplinkos, tikslo, struktūros ir veiklos perspektyvų.

\section{Tyrimo organizavimo ypatumai}

Moterys pasirinktos, atsižvelgiant ị jų socialinị statusą darbinės veiklos aspektu.

Viena jų - 59 metų, ištekejjusi, ilgai buvusi namų šeimininkè, laukianti pensijos, turinti 20 metų darbo stažą, užauginusi du vaikus, kurie gyvena atskirai. Šiuo metu dirba slaugytojos padejjejja. Savo materialinę padètị vertina kaip gerą (tyrime ją vadinsime Dalia).

Kitos amžius - 60 metų, turi 38 metų darbo stažą, tarnautoja, našlè. Užaugino du vaikus (tyrime ją užkodavome kaip Daną). Savo materialinę padètị vertina kaip patenkinamą.

Trečia - Vaiva, 57 metų, turinti 35 metų darbo stažą, ištekejjusi, pernai atleista iš darbo dèl etatų mažinimo, bedarbè. Užauginusi dukrą, kuri kartu su dviem savo vaikais ir vyru gyvena pas Vaivą. Savo materialinę padètį vertina kaip blogą.

Ketvirtoji - Birutè, 56 metų, aukštosios mokyklos dėstytoja, turinti 32 metų darbo stažą, ištekèjusi. Užaugino vieną dukrą, kuri Lietuvoje negyvena. Savo materialinę padètį vertina kaip puikią.

Penktoji - Daiva, 56 metų, užauginusi dukrą, kuri gyvena kitame mieste. Daiva turi 33 metų darbo stažą, dirba kaimo mokykloje mokytoja. Gyvena su vyru, slaugo šalia gyvenančią mamą. Turi anūkę. Materialinę padètị vertina gerai.

Pokalbis su kiekviena moterimi truko nuo 1,5 iki 2 valandų jų namuose, dalyvaujant tik moteriai ir tyrejjai. Respondentès supažindintos su tyrimo tikslais, eiga, rezultatų panaudojimo galimybėmis ir aplinkybėmis, pasirašè sutikimą dalyvauti tyrime. Jos supažindintos su tyrimo rezultatų interpretavimu ir neprieštaravo, kad jie būtų publikuoti.

\section{Rezultatai}

Kaip minèta, moterų savijautai ịtakos turinčius veiksnius pristatome, remdamiesi Jean-Lous Le Moigne, kuris teigia, kad aprašant bet kurị socialinị reiškinị 
visada vertinga žvelgti i jị raidos, aplinkos, tikslo, struktūros ir veiklos kontekste (plg., Ruškus, 1998-1999).

Moters savijautai įtakos turintys veiksniai raidos aspektu. Tyrimo rezultatai atskleide, kad raidos aspektu moters sveikatai įtakos turinčius veiksnius galima skirstyti ị genetinius ir biologinius. Juos dar galima skaidyti ị igimtus, pvz.: Visada buvau stambi (Dalia); Niekada nebuvau balerina (Dana); visada buvau jautri, tèvas sakydavo, neimk i galva, imk i pilva, bet man neišeidavo (Daiva); igytus, pvz.: Storèti pradejau prasidejus menopauzei (Daiva); Sveikata labai pablogèjo pašalinus kiaušides (Vaiva); Kai man pašalino kiaušides, atrodo, griuvo pasaulis (Birutė); Viskas pradejo griūti: pirmiausia skydliaukè, vèliau pasireiškè osteoporozé (Birutė); Jau daug metu esu be sveikatos: skydliauke, stuburo problemos, žarnyno problemos, cukralige (Vaiva). Išryškejjo ir šeimos tradiciju įtaka, pvz.: Tèvas stovédavo su diržu ir versdavo valgyti (Birutè); Kai aš pradèdavau verkti ar büdavau nelaiminga, visada gaudavau saldainiu (Vaiva); Vaikystè prabégo valgant bulves (Daiva).

Aplinkos reikšmė moters savijautai įtakos turintiems veiksniams. Kaip rodo tyrimo rezultatai, aplinka turi didelę reikšmę moters savijautai ir sveikatai. Išryškejjo nemažai veiksnių, kuriuos santykinai suskirsteme ị penkias grupes:

- Darbo sukeliamas stresas, pvz.: Darbe sukeliama ịtampa man neleidžia užmigti (Birute); Grižusi iš darbo valgau ir valgau, negaliu sustoti (Daiva); Dèl darbo negaliu nueiti net pas gydytoją (Dalia).

- Santykiai su šeima, pvz.: Vyras manęs nesupranta ir tai man kerta per nervus (Dalia); Man namai ir šeima yra ramybès uostas, jeigu namuose nebūtu ramybès, aš išprotéčiau (Dana).

- Santykiai su gydytojais, pvz.: Turiu nuostabia gydytoja, kuri visada man padès (Birutè); Su mano šeimos gydytoja niekada nepasitarsi, bijau net žodi pasakyti (Vaiva).

- Materialinè padètis, kurios aukštesni ekonominį statusą užimančios moterys neakcentuoja, tuo tarpu sunkiai besiverčiančiosios tai pabrěžia, pvz.: Neturiu pinigu dantims susitvarkyti, dèl to niekur negaliu išeiti (Vaiva); Dèl sveikatos labai noréčiau nuvažiuoti i sanatorija, tačiau negaliu sau to leisti (Dana).

- Itampa pasaulyje, pvz.: Pabudau nakti nuo žemai praskridusio lèktuvo garso, taip suspaudè širdì, kad prasidejo karas (Daiva); Man tiesiog plyšta širdis, kai dukte išvykusi, taip neramu dabar pasaulyje (Birutè).

Moters tikslai ir savijautai įtakos turintys veiksniai. Tikslų, turinčiu ịtakos moters savijautai ir sveikatai, požiūriu išryškẻjo keturios tarpusavyje koreliuojančios grupès, tai tikslai, susiję su: 
- Šeima, pvz.: Na, kur aš rasiu darba, kai turiu dukters vaikus prižiürèti, kas jeigu ne aš (Vaiva);

- darbu, pvz.: Reiketu mesti ta darba, bet kenčiu, pensija dar toli, o kito nerasiu (Daiva);

- gera sveikata, pvz.: Noréčiau, kad mano sveikata bütu geresné, todèl stengiuosi daug vaikščioti (Birutè);

- $\quad$ saviraiška, pvz.,: Šiaip noréčiau pakeliauti, bet nèra nei sveikatos, nei pinigu, todèl dažniausiai siuvinèju kryželiu, mane tai ramina (Vaiva).

Tyrimo rezultatai atskleidè, kad moterys linkusios aukoti gerą savijautą dèl darbo ir šeimos. Gera sveikata ir saviraiška, veikiančios savijautą, tarsi nustumiamos i antrą vietą ar paaukojamos, keičiamos kita veikla, kuri priimtinesnė kitiems, o ne pačiai moteriai (kompromiso ieškojimas), pvz., Labai noréčiau eiti ị linijinius šokius, bet vyrui nepatiktu, todèl darau mankšta namuose (Daiva).

Moters suvokimas, kokie veiksniai turi itakos jos savijautai. Pagrindinis žodis, kuris dominuoja moterų pasakojime ir susijęs su jų savijauta, yra stresas. Santykinai stresą galime skirstyti ị keturias grupes:

- Su darbu susijęs stresas, pvz.: Kiekviena ryta važiuodama ị darba aš jau pradedu nervintis, o vakare grižtu visai išsunkta (Birutė); Darbe aš su jaunomis nesuspejju, man viska skauda (Dalia).

- Su prasta materialine padètimi susijęs stresas, pvz.: Sūnus nori būti ponu, pasiemè paskola, nusipirko nama, tai aš naktimis nebemiegu (Dana).

- Su nerimu dèl ateities, pvz.: Man 59 metai, o turiu tik dvidešimt metu darbo stažą, sveikatos dirbti neturiu, kas bus toliau, kaip aš gyvensiu (Dalia).

- Ligų baimé, pvz.: skydliauke, stuburas, cukraligè, nuolat viduriuoju, kas bus toliau (Vaiva).

Moters kontroliuojama veikla padedanti / kenkianti jos savijautai ir sveikatai. Tyrimo rezultatai atskleidè moters kontroliuojamą veiklą, kuri padeda gerai savijautai, arba kenkia, jeigu kontrolè yra nepakankama. Santykinai moters kontroliuojamą veiklą suskirsteme ị keturias sritis. Pasakojimuose moterys dažniausia minèjo:

- Lankymąsi pas gydytojus, pvz.: Kiekvienais metais gulu i ligoninę, kad man pareguliuotu cukru (Vaiva); Noréčiau nueiti pas gydytoja, bet kada, kai tiek dirbu, dar ir ị darba turiu važinèti 30 kilometru (Dalia). Analizuojamoje situacijoje moterų kontroliuojama veikla labiau aktyvi negu pasyvi.

- Aktyvus laisvalaikis. Čia - priešingai, moterys nelinkusios aktyviai leisti laisvalaikio, pvz.: Na, kur aš eisiu pasivaikščioti, jeigu visai neturiu jegy (Vaiva); Man taip skauda kelius, kad aš džiaugiuosi prigulusi (Dalia); Ǎ̌ kiekviena savaitgali stengiuosi leisti gamtoje, vaikštau, važinejju dviračiu (Birutè). 
- Moterys, nelinkusios aktyviai leisti laisvalaikio, užsiima kita veikla, jų nuomone, gerinančia savijautą. Ją santykinai pavadinome malonia veikla, pvz.: Pailsiu žiūrèdama serialus (Dalia); Man geriausias poilsis - kryžiažodžiai, atsijungiu nuo visko (Dana).

- Išryškejo dar viena veikla - malda ar meditacija, pvz.: Kiekviena ryta važiuodama ị darba meldžiuosi, taip igaunu stiprybes visai dienai (Daiva); aš geriausiai pailsiu nuèjusi i vienuolyna (Vaiva); jūra yra dabar mano bažnyčia (Birutè).

\section{Rezultatų aptarimas}

Mokslo studija atskleidè, kad pagyvenusio amžiaus moterų savijautai ir sveikatai ịtakos turi šie veiksniai: žemas socialinis ir ekonominis statusas; su darbu susiję veiksniai - fizinio krūvio sukeliamas stresas bei psichologinis / fizinis smurtas. Moterų savijauta prasteja ir esant nepalankiai darbo bei šeimos sąveikai. Literatūros analizė atskleidė genetinių ir biologinių veiksnių, moterų dalyvavimo sveikatos priežiūros sistemoje svarbą, aplinkos, šeimyninių aplinkybių ịtaką. Aktyvi moters veikla kontroliuojant savo savijautą mokslineje studijoje siejama su sveika gyvensena ir asmens saviraiška.

Tiek literatūros analizèje, tiek moterų naratyvuose dominuoja nuolatinis stresas ir neigiama jo įtaka savijautai. Stresą sukelia daug veiksnių, tačiau tyrime dominuojantis streso pobūdis siejamas su darbine veikla.

Empirinio tyrimo rezultatai neprieštarauja mokslinių šaltinių analizèje aptiktiems veiksniams, juos papildo. Kaip mokslinèje literatūroje neišryškejjusius galètume ịvardinti šeimos tradicijų įtaką, palankių santykių su gydytojais svarbą bei nerimą dèl ateities. Literatūroje akcentuojama sveika gyvensena moterų pasakojamose istorijose turi visai kitas charakteristikas. Literatūroje pabrèžiama fizinės veiklos ir sveikos mitybos svarba, o tyrime fiziškai aktyvi yra tik viena iš moterų. Visos jos turi antsvorio ir emocinio valgymo problemų, dažnai persivalgo, nors apie sveiką mitybą žino pakankamai. Moterys linkusios savo gerą savijautą aukoti dèl šeimos interesų. Sureikšmina darbinès veiklos svarbą: renkasi darbą, o ne gerą savijautą.

Išanalizavus empirinio tyrimo medžiagą, galima ịžvelgti gerą savijautą lemiančių veiksnių sąveiką, pvz.: raminimosi maistu tradicijos, atejusios iš šeimos. Viršsvoris ne tik sukelia moterims sveikatos problemų, bet ir trukdo aktyviai leisti laisvalaikį, taip gerinant savo savijautą. Raminimasis maistu (šeimos tradicijos) trukdo sveikai maitintis ir gali lemti santykius su gydytojais (moterys tikisi „stebuklingos" piliulès). 
Empirinis tyrimas, nors ir atskleidè ekonominio statuso svarbą moterų savijautai, tačiau stresą, skirtingai nei aprašoma mokslo šaltiniuose, darbe patiria ir jo įtaką savijautai akcentuoja respondentès, užimančios tiek žemą, tiek ir aukštą socialinị statusą.

\section{Išvados}

1. Mokslo studija atskleidè, kad pagyvenusio amžiaus moterų savijautai ir sveikatai įtakos turi šie veiksniai: žemas socialinis ir ekonominis statusas; fizinio ar psichologinio krūvio darbe sukeliamas stresas; nepalanki darbo ir šeimos sąveika; genetiniai ir biologiniai veiksniai; moterų dalyvavimas sveikatos priežiūros sistemoje; šeimyninių aplinkybių įtaka; gyvenimo būdas ir asmens saviraiška.

2. Empirinio tyrimo rezultatai neprieštarauja mokslinių šaltinių analizèje aptiktiems veiksniams, juos papildo. Moterų istorijose išryškèjo šeimos tradicijų, palankių santykių su gydytojais svarba bei nerimo dèl ateities veiksnių itaka moterų savijautai ir sveikatai.

3. Empirinis tyrimas atskleidè, kad stresą, skirtingai negu antrinès mokslo šaltinių analizès duomenimis, darbe ir jo įtaką savijautai respondentès patiria, nepaisant jų socialinio statuso.

4. Empirinis tyrimas atskleidè, kad moterys, nors ir suvokia gyvenimo būdo bei asmens saviraiškos svarbą gerai savijautai ir sveikatai, tačiau mažai stengiasi aktyviai ir sveikai gyventi. Savo gerą savijautą jos linkusios aukoti dẻl profesinių ar šeimos interesų.

5. Tyrimas atskleide, kad savijautai ir sveikatai įtakos turintys veiksniai sąveikauja tarpusavyje, todèl domintis savijautai įtakos turinčiais veiksniais svarbu matyti jų visumą.

Gauta 20170312

Pasirašyta spaudai 20170522

\section{Literatūra}

Belle, D. (1990). Poverty and Women's Mental Health. American Psychologist, Vol. 45(3), p. 385-389. Prieiga internete: http://dx.doi.org/10.1037/0003-066X.45.3.385

Bird, C. E., Rieker, P. P. (1999). Gender matters: an integrated model for understanding men's and women's health. Social Science \& Medicine, Vol. 48, p. 745-755. Prieiga internete: http://dx.doi.org/10.1016/S02779536(98)00402-X

Bitinas, B., Rupšienè, L., Žydžiūnaitè, V. (2008). Kokybiniu tyrimu metodologija. Vadovèlis vadybos ir administravimo studentams. Klaipèda. 


\section{PAGYVENUSIO AMŽIAUS MOTERŲ SAVIJAUTAI İTAKOS TURINTYS VEIKSNIAI}

Burke, R. J. (2002). Work Stress and Women's Health: Occupational Status Effects. Journal of Business Ethics, Vol. 37 (1), p. 91-102. Doi:10.1023/A:1014734302972. Prieiga internete: http://link.springer.com/article/1 $0.1023 \% 2 \mathrm{FA} \% 3 \mathrm{~A} 1014734302972$ ?LI=true

Creswell, J. W. (2003). Research Design. Qualitative, Quantitave and Mixed Methods Approaches. SAGE Publications, p. 1-26.

Dadelo, S. (2013). Kūno kultūros ir sporto mokslo plètros aktualumas tarpdalykinių komunikacijų kontekste. Santalka: Filosofija, Komunikacija, Nr. 21 (1), p. 55-64.

De Fina, A., Georgakopoulou, A. (Ed.). (2015). The Handdbook of Narrative Analysis. A. Wiley Blackwel, 467 p.

Dooley, L., Slavich, G. M., Moreno, P., Bower, J. (2017). Strength through adversity: Moderate lifetime stress exposure is associated with psychological resilience in breast cancer survivors. Stress and Health, p. 1-9. Doi: 10.1002/smi.2739. Prieiga internete: http://onlinelibrary.wiley.com/doi/10.1002/smi.2739/full

Georgakopoulou, A. (2014). Between narrative analysis and narrative inquiry: The long story of small stories research. Urban Language and Literacies, Vol. 131, p. 1-17.

Gudžinskienė, V., Armonienė, J., Pocevičius, A. (2012). Fizinis aktyvumas kaip vienas sveikatą lemiančių veiksnių. Pedagogika, Vol. 105, p. 86-92.

Javtokas, Z. (2009). Sveikatos stiprinimo konspektas. Valstybinis psichikos sveikatos centras, Vilnius, 103 p.

Joyce, T., Bromberger, J. T., Harlow, S., Avis, N., Kravitz, H. M., Cordal, A. (2004). Racial / Ethnic Differences in the Prevalence of Depressive Symptoms Among Middle-Aged Women: The Study of Women's Health Across the Nation (SWAN). American Journal of Public Health, Vol. 94 (8), p. 1378-1385. Prieiga internete: https://www.ncbi.nlm.nih.gov/pmc/articles/PMC1448459

Juozulynas, A., Jurgelènas, A., Prapiestis, J., Butikis, M. (2010). Gyvenimo kokybès ir socialinių veiksnių tarpusavio ryšys. Gerontologija, Vol. 11 (1), p. 37-42.

Klizas, Š., Sipavičienè, S., Klizienè, I., Pliauga, V. (2012). Fizinio aktyvumo poveikis vyresnio amžiaus moterų psichofizinei sveikatai. Medicinos teorija ir praktika, Nr. 18 (3), p. 267-272.

Kuh, D. L., Wadsworth, M., Hardy, R. (1997). Women's health in midlife: the influence of the menopause, social factors and health in earlier life. An International Journal of Obstetrics \& Gynaecology, Vol. 104 (8), p. 923-933. Prieiga internete: http://onlinelibrary.wiley.com/doi/10.1111/j.1471-0528.1997.tb14352.x/full

Kuodytė-Kazilienė, R., Užaitė, R., Palinauskienė, R., Kuzinkovas, A., Šerytė, L., Ulianskienė, R. (2007). Streso, depresiškumo, nerimo paplitimas tarp sveikatos priežiūros ir švietimo darbuotojų Panevėžio mieste. Medicinos teorija ir praktika, Nr. 13 (4), p. 479-484.

Leonavičius, V., Baltrušaitytė, G., Raila, G., Naujokaite, I. (2013). Mediciniškai nepaaiškinami negalavimai vèlyvosios modernybės / posmodernybès socialiniu teorijų požiūriu. Kultūra ir visuomenè, Nr. 4 (1), p. 1135.

Matthews, K. A., Shumaker, S. A., Bowen, D. J., Langer, R. D., Hunt, J. R., Kaplan, M. R., Klesges, R. C., Ritenbaugh, C. (1997). Women's Health Initiative. Whay Now? What is it? What's New? American Psychologit, Vol. 52 (2), p. 101-116. Prieiga internete: http://dx.doi.org/10.1037/0003-066X.52.2.101

McDonough, P., Walters, V., Strohschein, L. (2002). Chronic stress and the social patterning of women's health in Canada. Social Science \& Medicine, Vol. 54 (5), p. 767-782. Prieiga internete: http://dx.doi.org/10.1016/ S0277-9536(01)00108-3

Rapolienè, G. (2007). Lietuvos pagyvenusių žmonių identitetas iš postmodernizmo perspektyvos. Gerontologija, Nr. 8(2), p. 109-116.

Repetti, R. L., Matthews, K. A., Waldron, I. (1989). Employment and women's health: Effects of paid employment on women's mental and physical health. American Psychologist, Vol. 44(11), p. 1394-1401. Prieiga internete: http://dx.doi.org/10.1037/0003-066X.44.11.1394

Ruškus, J. (1998-1999). Sisteminè analizė: koncepcijos raida ir perspektyvos. Socialiniai tyrimai: tarpdisciplininis požiūris, Nr. 2-3, p. 104-116.

Sanjay, K., Pandey, S. K., Hart, J. J., Tiwary, S. (2003). Women's health and the internet: understandingemerg ingtrends and implications. Social science and Medicine, Vol. 56, p. 179-191. Prieiga internete: http:// dx.doi.org/10.1016/S0277-9536(02)00019-9

Sutherland, C. A., Bybee, D. J., Sullivan, C. M. (2002). Beyond Bruises and Broken Bones: The Joint Effects of Stress and Injuries on Battered Women's Health. American Journal of Community Psyhology, Vol. 30 (5), p. 609-635. Prieiga internete: http://onlinelibrary.wiley.com/doi/10.1023/A:1016317130710/full 
Šurkienė, G., Stukas, R., Kučingis, Š., Strujeva, O. (2004). Gyventojų, gyvenančių ir dirbančių rizikos aplinkoje, požiūris ị savo sveikatą bei kai kurių socialinių santykių įtaka savo sveikatos vertinimui. Sveikatos mokslai, p. 6-9.

Ustinavičienė, R., Obelenis, V., Ereminas, D. (2004). Dirbančiujų sveikata ir šiuolaikinės darbo sąlygos. Medicina (Kaunas), Nr. 40 (9), p. 897-904.

\section{THE FACTORS DETERMINING WELL-BEING OF ELDERLY WOMEN}

\section{Nijolè Šostakienè, Ingrida Baranauskienė}

\section{Summary}

A changing socio-economic situation, constant stress at work and in personal life, receding retirement age and increasing tension in the world in general highly influence well-being of people. As far back as in the previous century, an active discussion on what determined health of men and women - biological or social factors - took place (Bird, Rieker, 1999). Even though "the impact of biological factors, such as genetics, (...) impact of hormones, is very important, health of both women and men is not less influenced by social processes, too" (Bird, Rieker, 1999, p. 745). These processes may "determine - either improve or impede - biological health" (ibid.). The authors hold the opinion that this should be understood by researchers, doctors, politicians and people in general; also, they should solve the related challenges (Bird, Rieker, 1999). Lithuanian researchers Šurkienè, Stukas, Kučingis et al. found out that "women assessed their health poorer than men" (Šurkienè, Stukas, Kučingis, Strujeva, 2004, p. 9).

The article presents a qualitative research, a narrative, which is constructed on the ground of the works carried out by De Fina, Georgakopoulou (2015); Creswell (2003); Georgakopoulou (2014); Bitinas, Rupšienè, Žydžiūnaitė (2008) and our independently, though being influenced by the mentioned researchers, formed understanding about the narrative as a conception of the research. Paraphrasing Georgakopoulou, it can be stated that our narrative means five short stories merged into one narrated story, cf. Georgakopoulou (2014), which aims at perceiving the factors making impact on elderly women's health from the standpoint of the respondents.

In introducing research results, we used the model of systemic analysis constructed by Jean-Lous Le Moigne, analysed by Ruškus (1998-1999). Jean-Lous Le Moigne has it that when describing any social phenomenon it is always worth 
viewing it from the perspectives of development, environment, purpose, structure and activity. The scientific study reveals that elderly women's well-being and health is influenced by the following factors: low social and economic status; work-related factor: stress caused by physical and psychological / physical violence. Women's well-being also worsens under existing unfavourable interaction of work and family. Analysis of literature reveals importance of genetic and biological factors, women's participation in the health care system, influence of environment, family circumstances. The study relates woman's active performance when controlling her well-being to a healthy lifestyle and personal self-expression.

In both literature analysis and women's narratives constant stress and its negative impact on well-being dominates. Stress is caused by many factors; however, the character of stress prevailing in the research is related to work performance.

Results of the empirical research do not contradict the factors found in the scientific study, they rather complement them. We would name several factors which were not emphasised in scientific literature: influence of family traditions, importance of favourable relations with doctors and anxiety about the future. Moreover, a healthy lifestyle underlined in surveyed literature obtains completely different characteristics in the stories narrated by the surveyed women. If in the literature importance of physical activities and healthy nutrition is emphasised, among the surveyed women there is only one respondent who is physically active. All they have problems of overweight, emotional eating, frequent over-eating, even though they have sufficient knowledge on healthy nutrition. These women tend to sacrifice their well-being in favour of family interests. They give work activities prominence and choose work instead of good well-being.

Deeper analysis of empirical research materials allows noticing interdependence of the factors influencing good well-being, e.g. traditions of comforting food reach us from the family environment. Overweight not only causes health problems to women but also prevents from active leisure time making well-being better. Comforting food (family traditions) prevents from healthy nutrition and may decide the relations with doctors (women expect to get a "magic" pill).

Even though the empirical research emphasised importance of an economic status to women's well-being, still stress and its impact on well-being were experienced at work by the respondents holding both low and high social status, differently from the scientific study referred to. 
